Article

\title{
Impact of Political Connection Strength on the Internationalization Outcome of Chinese Firms: Perspectives from Market Exploration and Technology Acquisition
}

\author{
Gupeng Zhang ${ }^{1, * \mathbb{D}}$, Qianlong Zhang ${ }^{1}$ and Dujuan Huang ${ }^{2}$ \\ 1 School of Public Policy and Management, University of Chinese Academy of Sciences, Beijing 100049, China; \\ zhangqianlong17@mails.ucas.ac.cn \\ 2 College of business administration, Anhui University of Finance and Economics, Bengbu 233030, China; \\ huangdujuan@aufe.edu.cn or dujing1985@163.com \\ * Correspondence: zhanggupeng@ucas.ac.cn
}

Received: 21 January 2020; Accepted: 18 February 2020; Published: 21 February 2020

\begin{abstract}
Although the role of a home country's government in firms' internationalization processes has been investigated, there is a gap in the literature concerning the effectiveness of the government's effort. Based on the data of 1996 Chinese listed firms, this study investigates how the strength of Chinese firms' political connection with their home country government impacts the outcomes of their internationalization activities. These activities are classified into market exploration and technology acquisition. We establish an index to measure the firms' political connection strength and find that it exhibits a bimodal distribution, which indicates that some firms maintain a close relationship with the government, while the business activities of others are distant from the government. The strength of the political connection has different moderating effects on firms' internationalization processes when either the international market context or the firms' internationalization activities vary. A strong political connection is beneficial for firms to explore the markets and acquire beneficial technology from developed countries. Compared with its role in exploring international markets, political connection plays a more significant moderating role in augmenting the positive effect of international technology acquisition on firms' innovation capability. Therefore, Chinese firms may perform better in the internationalization process if they maintain a close relationship with the Chinese government, which engages in promoting the internationalization of domestic firms through an array of policies that may compensate for the firms' disadvantages. Our results show the mechanism through which emerging countries' governments use directives and incentives to facilitate the internationalization of domestic firms.
\end{abstract}

Keywords: political connection strength; market exploration; technology acquisition; internationalization; home country government

\section{Introduction}

In recent years, more Chinese firms have started to increase their international investment and acquisition activities with the intention of expanding to international markets and acquiring advanced technologies [1-3]. The internationalization of Chinese firms has become an increasingly important research topic [4-7]. This is not only a micro-level manifestation of China's economic rise to the changes in the world economic structure, but it also triggers a new wave of globalization and introduces a new look into the world market structure and global innovation. As a latecomer to internationalization, Chinese firms do not have the original advantages in market, capital, and innovation capability of other 
countries' firms. However, these firms have caught up and even surpassed multinational corporations (MNCs) from developed countries in certain industrial sectors, such as telecommunications and high-speed railway [8,9]. Investigating the driving forces behind the internationalization of Chinese firms is the key to unlocking the mystery of the accelerating internationalization of firms from emerging countries [10-12].

The increasing weight of Chinese firms in the global market can—to a great extent-be attributed to the Chinese government $[4,13]$, which has issued a number of policies and support strategies to promote the "going out strategy," such as providing financial incentives (tax incentives, tax breaks, and low-interest loans) for "going out" firms, encouraging domestic firms to acquire international high-tech firms and establish international branches, and signing national bilateral and multilateral treaties to promote international investment [11]. Therefore, compared with the internationalization of MNCs from developed countries, that of Chinese firms is usually accompanied by government promotion and-to some extent-reflects the government's purpose [10,11,14-16].

The political connection between firms and their home country government may have a notable impact on the internationalization activities of these firms. The Chinese government- to a great extent-determines how firms choose alliances and acquisitions to establish linkages, which eventually affects their international market expansion path and the outcomes of internationalization [17,18]. Most existing studies in this research area focus on the impact of firms' political connections with the home country government on their performance in the domestic market (e.g., [19,20]), while the impact on firms' performance in the international market has not been sufficiently discussed. In studies that explored the internationalization strategies, motivations, comparative advantages, and catch-up of firms from emerging economies, the firm characteristics—such as size and ownership, international $R \& D$ (Research and Development) strategies, and managerial intent-are widely investigated (e.g., $[11,15,21-26])$, while the role of firms' home country government is insufficiently examined. Although existing studies have focused on the Chinese government's strong promotion of international Mergers and Acquisitions (M\&A) and Outward Foreign Direct Investment (OFDI) (e.g., [15,18,27]), they offer insufficient knowledge concerning the consequences of these internationalization activities. Other studies have examined the relationship between firms' internationalization and the institutional environment of the host countries where the firms invest (e.g., [28-30]), while the role of the political connection with the home country government-particularly with a national government-that has the ambition of increasing its international influence, is insufficiently discussed.

To fill in this gap, this study investigates how the strength of Chinese listed firms' political connections with the Chinese governments (both central and local governments) impacts their internationalization outcomes. We measure the internationalization outcomes from two perspectives: market exploration and technology acquisition, which are viewed by previous studies as two of the most important objectives of firms' internationalization activities [10,11,13,31,32]. We also empirically test the effect of these political connection strengths in the international market of both developed and developing countries. We aim to discover whether government-promoted internationalization activity has different outcomes in essentially distinct international market contexts, and how the political connection strength generates an impact on firms with different internationalization motives. This study contributes to existing literature from the following three perspectives: First, by accounting for the role of the Chinese government, we provide further knowledge concerning the distinct internationalization processes of Chinese firms, which could also be indicative of government-backed internationalization activities carried out by firms from other emerging countries. Second, we construct an index to measure the political connection strength between governments and firms, which enriches the literature that defined and measured political connections with information on firm executives and the board of directors (e.g., [33-35]). As the Chinese government is deeply involved in businesses and resource allocation [36], it appears impossible for firms to stay entirely independent of the government, particularly large or state-owned firms. In this case, merely discovering that a political connection exists (e.g., $[19,20,35,37])$ may not be sufficient, as a close relationship with the government may bring 
about different consequences for firms than having a weaker relationship. It is therefore necessary to introduce an index to measure the political connection strength. Third, to investigate the role of political connections in different circumstances, we divided international markets according to countries' economic statuses and classified the firms' internationalization motives into either market or technology oriented. In this sense, we extend existing knowledge by empirically testing the role of political connections in different market contexts and for firms with different internationalization motives.

The rest of this paper is organized as follows: Section 2 presents the theory and hypotheses, while Section 3 provides the data and methods. Section 4 presents the empirical results, Section 5 discusses the results, and Section 6 provides a conclusion and the implications of the study.

\section{Theory and Hypotheses}

Due to the decrease in domestic economic growth, Chinese firms are eager to invest in international markets to seek new opportunities [12]. Chinese firms are also attempting to acquire advanced technology to upgrade production to enable them to compete with MNCs from developed countries $[4,6,38]$. Therefore, this study examines the impact of political connection on the internationalization outcomes of Chinese firms from the perspectives of market exploration and technology acquisition.

\subsection{Political Connection and International Market Exploration}

A firms' strategic choices are not only determined by its specific capabilities and industrial basis, but also by the constraints imposed by the institutional environment [39]. Many emerging countries' governments play an important role in formulating the international business strategies of domestic firms $[4,16,40]$. The home country system not only provides firms with unique advantages in products, but also provides political advantages to manage political risks in other countries.

First, a strong political connection has become an important tool for Chinese firms to access preferential policies and resources. Chinese MNCs can rely on their political connections to enable them to utilize domestically rich and cheap labor, low operating costs, loose government regulations, and a large market with rapid economic growth and a population of more than one billion people $[4,41]$. These firms can also take advantage of government-provided preferential policies, such as financial loan support and subsidies, and will have more resources that enable them to participate in the global supply chain [16]. The government also promotes OFDI through specific policies to compensate for the firms' disadvantages in international competition $[1,4,10]$.

Second, the Chinese government actively breaks down international barriers by signing bilateral or multilateral treaties with other countries. For example, Chinese president Xi Jinping proposed the "Belt and Road" initiative in 2013, which is intended to promote the internationalization of Chinese firms by opening up the international market and realizing the transfer of backward domestic production capacity through government effort [42,43]. The government treaty is a vast driving force that promotes the growth of international M\&A and OFDI. Government policies are essential to the internationalization of Chinese firms, as government support in China is an active agent [40].

Third, frequently interacting with the Chinese government increases firms' experience in addressing the risks in the process of internationalization. A firm's strategic choice is not only affected by its indigenous resources and capabilities, but also by the institutional environment [39]. As Chinese firms are getting accustomed to using their political connection as an important institutional advantage, they have higher organizational capacity to manage policy risks and are less sensitive to the risks associated with other countries' policies. Considering the large segment of the international market that is usually accompanied by high risks, Chinese firms recently appear to be more aggressive, compared with the cautious attitudes of MNCs from developed countries [6,7,44].

Accordingly, we propose the following hypothesis: 
Hypothesis 1. A strong political connection with the Chinese government is beneficial for Chinese firms to explore the international market.

\subsection{Political Connection and Technology Acquisition}

The Chinese government prioritizes international technology transfer as a matter of policy and provides both direct and indirect support to firms engaging in acquiring international technologies and merging with international high-tech firms [45]. Although the M\&As and OFDI carried out by Chinese firms are usually suppressed by foreign government in question for being highly connected with the Chinese government-for example, the ban on Huawei and ZTE (Zhongxing Telecommunication Equipment Corporation) and the termination of acquiring Philips Lumileds carried out by China's Jinshajiang Venture Capital-the Chinese government still plays an active and important role in Chinese firms' promotion of innovation performance through international R\&D investment. For example, firm managers with strong political connections-especially those managing state-owned firms that are more likely to be supported by Chinese government [46] - have more opportunities to accompany the government leaders to attend foreign visits, with the intention of signing technical treaties with international firms [4,47]. The Chinese government also provides financial support for domestic firms to merge with international high-tech firms and acquire international technologies $[4,48]$. For example, in the semiconductor industry, the Chinese government has established at least $\$ 107$ billion in investment funds to finance increases in domestic capacity and Chinese firms' acquisitions abroad. Furthermore, Chinese firms' international investment and acquisition reflects the direction of the Chinese government, who intends to obtain cutting-edge technologies and foster technology transfer in strategic industries that it intends to prioritize [45].

Accordingly, compared with MNCs from developed countries, Chinese firms are more reliant on their home country government to gain global technological resources [1]. Gaining the government support and promoting OFDI and M\&A is beneficial for firms to overcome their disadvantages in the global market and to acquire important strategic resources, such as advanced technologies [11, 41,49]. A strong political connection assists firms in achieving technological upgrades through internationalization and helps them to establish multiple information channels, policy preferences, and other important international relationships [39]. By joining the government in promoting international M\&A, Chinese firms successfully integrated many international innovation facilities and platforms with their own innovation resources [50].

Based on the above, we propose the following hypothesis:

Hypothesis 2. A strong political connection with the Chinese government helps Chinese firms to acquire beneficial international technology, thereby improving their innovation capabilities.

\section{Data and Method}

\subsection{Data}

Firms listed in the Shenzhen and Shanghai Stock Exchanges were selected as our research objects. To simplify the data, we excluded financial firms with very few R\&D investments, Special Treatment (ST) firms with abnormal interference in their daily production and operation, and firms whose international operations have not been clearly disclosed. Our final sample consisted of 1996 listed firms. We collected the following information of these listed firms from the annual financial reports and Wind database for the period 2013-2016: the names of chairpersons and managers, international assets and investments, international M\&A, R\&D input, and other financial data. As there was missing data for some firms in some years, we constructed an unbalanced panel dataset that contained 6092 observations. 


\subsection{Dependent Variables}

We employed the logarithm of the firm's international revenue (Ln_overseas_revenue ${ }_{i, t}$ ) to measure the outcome of its international market exploration. The subscripts $i$ and $t$ denote the firm and year respectively. A higher international revenue reflects a larger market scale in host countries. This variable was also employed by [51-53] to measure the scale of the international market.

We employed the logarithm of the invention patent count (Ln_patent $\left.t_{i, t}\right)$ filed by firms to represent the outcome of their technology acquisition. This means that if a firm successfully introduces beneficial technologies from other countries, its innovation capability would be improved, and it will therefore file more patents. Patent count is often used as an alternative variable to measure technological innovation [35] and is therefore widely used as an important indicator of innovation output or productivity [54]. Data concerning firms' invention patents were collected from the National Intellectual Property Administration, PRC (CNIPA) (Formerly known as the State Intellectual Property Office of China (SIPO)).

\subsection{Independent Variables}

\subsubsection{Measuring the Political Connection Strength}

If at least one of the firm's major shareholders or top managers is a member of parliament, a minister, or is closely related to top politicians or a political party, the firm is identified as having political ties [33]. Existing literature focusing on the political connections of Chinese firms investigated whether the firm's chairperson or general manager is currently a government official, a National People's Congress (NPC) representative, or a Chinese People's Political Consultative Conference (CPPCC) member (e.g., [55,56]). However, the strength of the relationships between the firms and the government may differ between firms and may lead to different consequences, and the above measurement barely accounts for this fact. Therefore, to complement existing studies, we constructed the "Political Connection Strength" index to measure this closeness.

As Chinese firms are impacted mostly by central and local governments [57], we accounted for the firms' political connection strength on both a national and provincial level. To do this, we collected the names of the representatives of the Eleventh (2008) and Twelfth (2013) National and Provincial People's Congresses, the National and Provincial Committee of the Chinese People's Politic Consultative Conference, and the National Party Congresses at the Seventeenth (2007) and Eighteenth (2012) National Congresses. We matched these name lists with the chairpersons and general managers of the listed firms. Subsequently, we obtained information concerning whether the firms' chairpersons and general managers also act as representatives in the government congress.

Next, we noted the government position of the firms' chairpersons and general managers identified in the previous step, including whether they have either previously served or are currently serving as provincial-ministerial level officers, bureau-director level officers, or division-head level officers in the government.

Besides the political connections of firms' chairpersons and general managers, we also accounted for the firms' ownership (central firms, state-owned firms, and private firms), because the former two firm types are believed to have stronger political connections than the latter [55].

We developed a questionnaire to survey the strength of the political connections embedded in each of the above items. To ensure the intelligibility of our questionnaire items, we held informal interviews with eight experts before the implementation of the survey and asked them to point out ambiguous, vague, or unfamiliar terms. We then incorporated their feedback into the questionnaire to improve its readability and relevance. Based on these interviews, the questionnaire was refined, and the survey process was finalized.

The survey was then conducted using a professional survey website. We invited 308 relevant experts, formulated by university professors, government officials, and firm managers who we believed were very familiar with the government-firm relationship in China and its effects, to visit the website 
and score a point within the predetermined range $(0=$ no correlation between the government and the firm to $10=$ extremely high correlation between the government and the firm) for each item. The questionnaires were distributed for three months, and of the 130 respondents, 104 provided fully valid responses to the questionnaire that could be used in the analysis.

To check for non-response bias, we first compared the responding $(n=130)$ and non-responding experts $(n=178)$ in terms of attributes such as academic title, sex, and age using the $t$-test. All $t$-statistics were found to be insignificant. We then split the total sample into two groups based on the responding time [58]. The responses of late respondents-those who responded a week later-were compared to the responses of early respondents, those who responded within a week. A comparison of the two groups revealed no significant differences. Therefore, non-response bias was not expected to be a serious problem, and it was evident that the survey results were generally representative.

We employed a Cronbach's $\alpha$ coefficient to test the reliability of the items in the questionnaire. Table 1 shows that the Cronbach's $\alpha$ coefficients of these variables were all greater than 0.6 , which shows favorable internal consistency between questionnaires and the scale. The Kaiser-Meyer-Olkin (KMO) test and Bartlett's test were employed to test the validity of the questionnaire. As Table 1 shows, the KMO values were all greater than 0.5 , which shows good validity. We averaged all the respondents' scores to determine the average political connection strength of each item. As shown in Table 1 , the political connection strength of each item ranged between 4.88 and 6.65 points. Central and state-owned firms have stronger political connections than private firms. Moreover, the higher the government position held by the chairperson or general manager, the stronger the political connection. Representatives of the national congress were assigned a higher value to the firm's political strength, compared with that of provincial congress.

Next, we calculated each firm's political strength based on the data presented in Table 1. The firm will get the item score if its ownership, chairperson, or general manager fulfil that item. By adding up all the item scores, we obtained the political connection strength of a firm. Figure 1 shows a histogram of the political connection strength of 1996 listed firms, which exhibits a bimodal distribution. There were 1401 firms whose political connection strength ranges between 4 and 5 points, which takes a much larger ratio, compared with those whose political connection strength range between 9 and 10 points. The bimodal distribution reflects a polarization of political connection strength: some firms maintain a close relationship with the government, while most others are relatively distant. Next, we took the logarithm of the political connection strength presented in Figure 1 and introduced the variable $L n_{-}$Polit_connect_stren . $_{\text {. }}$

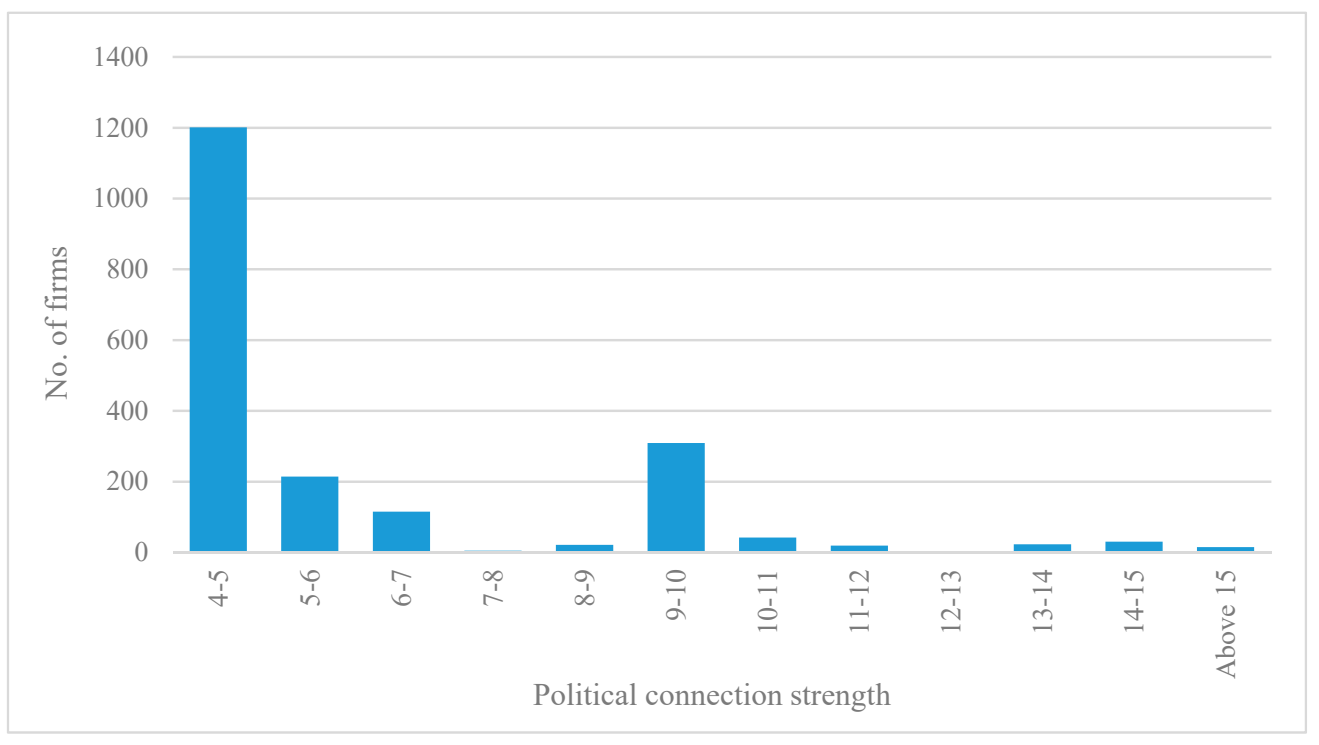

Figure 1. Distribution of the political connection strength of listed firms. 
Table 1. Measurements of the political connection strength.

\begin{tabular}{|c|c|c|c|c|c|}
\hline & Items & Mean & Std. Dev. & Cronbach's $\alpha$ & $\mathrm{KMO}^{\mathrm{a}}$ and Bartlett's Test \\
\hline $\begin{array}{l}\text { Congress representative } \\
\text { (Board chairperson) }\end{array}$ & $\begin{array}{l}\text { 1. Representative of the National Congress of the Communist Party of China (NCCPC) } \\
\text { 2. Deputy to the National People's Congress (NPC) } \\
\text { 3. Member of the National Committee of the Chinese People's Political Consultative Conference (CPPCC) } \\
\text { 4. Deputy to the Provincial People's Congress } \\
\text { 5. Member of the Provincial Committee of the Chinese People's Political Consultative Conference }\end{array}$ & $\begin{array}{l}4.61 \\
4.26 \\
4.16 \\
5.02 \\
4.40\end{array}$ & $\begin{array}{l}3.65 \\
3.43 \\
3.43 \\
3.26 \\
3.16\end{array}$ & 0.96 & $\begin{aligned} \mathrm{KMO} & =0.86 \\
\chi^{2} & =457.08 \\
\mathrm{df} & =10 \\
\mathrm{Sig} . & =0.00\end{aligned}$ \\
\hline $\begin{array}{l}\text { Government position } \\
\text { (Board chairperson) }\end{array}$ & $\begin{array}{l}\text { 6. Provincial-ministerial level officer } \\
\text { 7. Bureau-director level officer } \\
\text { 8.Division-head level officer }\end{array}$ & $\begin{array}{l}6.00 \\
5.16 \\
4.47\end{array}$ & $\begin{array}{l}3.92 \\
3.87 \\
3.51\end{array}$ & 0.94 & $\begin{array}{c}\mathrm{KMO}=0.69 \\
\chi^{2}=245.01 \\
\mathrm{df}=3 \\
\text { Sig. }=0.00\end{array}$ \\
\hline $\begin{array}{l}\text { Congress representative } \\
\text { (General manager) }\end{array}$ & $\begin{array}{l}\text { 9. Representative of the National Congress of the Communist Party of China (NCCPC) } \\
\text { 10. Deputy to the National People's Congress (NPC) } \\
\text { 11. Member of the National Committee of the Chinese People's Political Consultative Conference (CPPCC) } \\
\text { 12. Deputy to the Provincial People's Congress } \\
\text { 13. Member of the Provincial Committee of the Chinese People's Political Consultative Conference }\end{array}$ & $\begin{array}{l}4.72 \\
4.72 \\
4.67 \\
4.28 \\
4.05\end{array}$ & $\begin{array}{l}3.61 \\
3.35 \\
3.34 \\
3.20 \\
3.17\end{array}$ & 0.98 & $\begin{array}{c}\mathrm{KMO}=0.80 \\
\chi^{2}=626.39 \\
\mathrm{df}=10 \\
\text { Sig. }=0.00\end{array}$ \\
\hline $\begin{array}{l}\text { Government position } \\
\text { (General manager) }\end{array}$ & $\begin{array}{l}\text { 14. Provincial-ministerial level officer } \\
\text { 15. Bureau-director level officer } \\
\text { 16. Division-head level officer }\end{array}$ & $\begin{array}{l}5.35 \\
4.93 \\
4.75\end{array}$ & $\begin{array}{l}3.61 \\
3.53 \\
3.38\end{array}$ & 0.68 & $\begin{array}{c}\mathrm{KMO}=0.68 \\
\chi^{2}=259.12 \\
\mathrm{df}=3 \\
\text { Sig. }=0.00\end{array}$ \\
\hline Firm ownership & $\begin{array}{l}\text { 17. Central firm } \\
\text { 18. State-owned firm } \\
\text { 19. Private firm }\end{array}$ & $\begin{array}{l}6.65 \\
5.14 \\
4.88\end{array}$ & $\begin{array}{l}3.90 \\
3.55 \\
3.09\end{array}$ & 0.61 & $\begin{array}{c}\mathrm{KMO}=0.57 \\
\chi^{2}=138.99 \\
\mathrm{df}=3 \\
\text { Sig. }=0.00\end{array}$ \\
\hline
\end{tabular}

Note: ${ }^{a} \mathrm{KMO}$ is the acronym of Kaiser-Meyer-Olkin. The respondents are requested to score a point within the range $0-10$ for each item. The value of the score is proportional to the

political connection strength that the respondents assigned to the item. 


\subsubsection{Representation of Firms' Internationalization Activity}

As firms' internationalization activity may exhibit different patterns and may vary according to market contexts, we introduced several variables to comprehensively represent it:

First, following $[59,60]$, we employed the logarithm of international assets (Ln_overseas_assets ${ }_{i, t}$ ) to represent the firms' internationalization activity.

Then, by introducing the dummy variable $R D_{\text {_center\&collaboration }}$, which takes 1 if firm $i$ has established international R\&D centers or has collaborated with international firms on R\&D and 0 otherwise, we accounted for the internationalization from the perspective of technology innovation.

As developed and developing countries are essentially different from each other in terms of factors such as legal institutions, market risk, and market freedom [61,62], we differentiated these two country cohorts by identifying the OECD (Organization for Economic Co-operation and Development) and non-OECD countries as the developed and developing countries, respectively. We then independently represented the firms' internationalization activity in these two country cohorts. Because the annual reports present only the countries where the establishment of branches or M\&A occurred and the investment amount by countries, we introduced the following four dummy variables:

Branch_developed $_{i}$, which takes 1 if firm $i$ established branches in developed countries, and 0 otherwise.

Brahch_developing, which takes 1 if firm $i$ established branches in developing countries, and 0 otherwise.

M\&A_developed $i$, which takes 1 if firm $i$ merged with or acquired an international firm with headquarters in developed countries, and 0 otherwise.

$M \& A \_$devoping $i$, which takes 1 if firm $i$ merged with or acquired a firm with headquarters in developing countries, and 0 otherwise.

The political connection usually does not generate a significant effect in the short term, but it is an important intangible asset that improves the long-term social performance and market value [63-66]. This may be because political connection affects the way resources can be acquired, developed, and exploited [67]. This, in turn, impacts the firms' performance. Therefore, political connection is more likely to generate an indirect impact in firms' internationalization processes. Accordingly, we tested the above hypotheses by examining how political connection strength moderates the impact of the internationalization activities described by the above variables on the outcome of firms' internationalization. A significantly positive moderating role of political connection would provide further evidence for the above two hypotheses.

\subsection{Control Variables}

To control for other impacts, we introduced the following variables:

Listing_year ${ }_{i}$ : firm i's listing year in the Shenzhen or Shanghai Stock Exchanges.

East $t_{i}$ : which takes 1 if firm $i$ have headquarters in east China (East China consists of the following provinces: Hebei, Beijing, Tianjin, Shandong, Jiangsu, Zhejiang, Shanghai, Liaoning, Guangdong, Hainan, and Fujian.).

Middle $_{i}$ : which takes 1 if firm $i$ has headquarters in central China (Central China consists of the following provinces: Shanxi, Jilin, Heilongjiang, Anhui, Jiangxi, Henan, Hubei, and Hunan).

Ln_total_assets $i_{i, t}$ : the logarithm of the firm's total assets.

$L n_{-} s t a f f_{i, t}$ : the logarithm of the number of a firm's personnel.

$L n_{-} R D \_s t a f f_{i, t}$ : the logarithm of the number of a firm's R\&D personnel.

$L n \_R D \_$investment ${ }_{i, t}$ : the logarithm of a firm's R\&D investment.

The summary statistics and correlation coefficients of the dependent and independent variables are presented in Table 2. 
Table 2. Summary statistics and correlation coefficients of variables.

\begin{tabular}{|c|c|c|c|c|c|c|c|c|c|c|c|c|c|c|c|c|c|c|c|}
\hline Variables & Mean & Standard Deviation & Min. & Max. & 1 & 2 & 3 & 4 & 5 & 6 & 7 & 8 & 9 & 10 & 11 & 12 & 13 & 14 & 15 \\
\hline 1. Ln_overseas_revenue ${ }_{i, t}$ & 18.72 & 2.28 & 7.49 & 25.19 & & & & & & & & & & & & & & & \\
\hline 2. Ln_patent $t_{i, t}$ & 2.53 & 1.73 & 0 & 9.22 & 0.20 & & & & & & & & & & & & & & \\
\hline 3. Listing_year $r_{i}$ & 2008.40 & 6.98 & 1990 & 2018 & -0.28 & -0.01 & & & & & & & & & & & & & \\
\hline 4. East ${ }_{i}$ & 0.77 & 0.42 & 0 & 1 & 0.03 & -0.02 & 0.22 & & & & & & & & & & & & \\
\hline 5. Middle $_{i}$ & 0.15 & 0.35 & 0 & 1 & 0.00 & 0.03 & -0.16 & -0.77 & & & & & & & & & & & \\
\hline 6. $L n \_s t a f f_{i, t}$ & 7.61 & 1.22 & 3.00 & 12.59 & 0.56 & 0.33 & -0.46 & -0.11 & 0.08 & & & & & & & & & & \\
\hline 7. Ln_total_assets $s_{i, t}$ & 21.73 & 1.36 & 17.88 & 27.96 & 0.52 & 0.27 & -0.56 & -0.14 & 0.09 & 0.83 & & & & & & & & & \\
\hline 8. $L n \_R D \_s t a f f_{i, t}$ & 5.89 & 1.27 & 1.10 & 12.23 & 0.44 & 0.35 & -0.36 & -0.05 & 0.05 & 0.79 & 0.70 & & & & & & & & \\
\hline 9. Ln_RD_investment $t_{i, t}$ & 17.73 & 1.37 & 9.31 & 23.27 & 0.45 & 0.43 & -0.28 & 0.00 & 0.02 & 0.68 & 0.70 & 0.74 & & & & & & & \\
\hline 10. Ln_overseas_assets $s_{i, t}$ & 1.94 & 5.86 & 0 & 26.23 & 0.19 & 0.03 & -0.07 & 0.02 & -0.02 & 0.15 & 0.21 & 0.14 & 0.15 & & & & & & \\
\hline 11. Branch_developed ${ }_{i}$ & 0.24 & 0.42 & 0 & 1 & 0.18 & 0.04 & -0.02 & 0.08 & -0.07 & 0.06 & 0.09 & 0.10 & 0.13 & 0.14 & & & & & \\
\hline 12. Brahch_developing ${ }_{i}$ & 0.08 & 0.28 & 0 & 1 & 0.16 & 0.06 & 0.00 & 0.01 & 0.02 & 0.11 & 0.11 & 0.11 & 0.12 & 0.12 & 0.03 & & & & \\
\hline 13. M\&A_developed & 0.11 & 0.32 & 0 & 1 & 0.15 & 0.02 & -0.05 & 0.02 & -0.02 & 0.10 & 0.12 & 0.15 & 0.12 & 0.24 & 0.22 & 0.08 & & & \\
\hline 14. $M \& A \_$developing ${ }_{i}$ & 0.02 & 0.13 & 0 & 1 & 0.10 & 0.02 & -0.03 & -0.02 & 0.02 & 0.07 & 0.10 & 0.06 & 0.07 & 0.09 & 0.03 & 0.15 & 0.03 & & \\
\hline 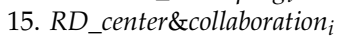 & 0.13 & 0.33 & 0 & 1 & 0.10 & 0.10 & -0.03 & 0.00 & 0.00 & 0.12 & 0.13 & 0.15 & 0.17 & 0.12 & 0.12 & 0.10 & 0.20 & 0.04 & \\
\hline 16. Ln_Polit_connect_stren & 1.79 & 0.32 & 1.58 & 3.13 & 0.12 & 0.13 & -0.19 & -0.16 & 0.13 & 0.24 & 0.29 & 0.21 & 0.18 & 0.02 & -0.02 & 0.05 & -0.02 & 0.01 & 0.08 \\
\hline
\end{tabular}




\section{Empirical Results}

As our data are panel data, we employed a panel model and chose a Random Effect (RE) setting based on the results of a Hausman test. As shown in Table 3, Models 1, 2, and 3 test Hypothesis 1 by taking Ln_overseas_revenue $i, t$ as the dependent variable. The insignificant parameter estimate of Ln_overseas_assets $i, t$ in Model 1 suggests that holding more international assets does not necessarily increase a firm's international revenue. Furthermore, we found that the parameter estimate of the interaction term Ln_Polit_connect_stren ${ }_{i} \times$ Ln_overseas_assets $_{i, t}$ is not significant in Model 1, which suggests that political connection strength does not positively moderate the impact of international assets on international revenue. This indicates that Hypothesis 1 is not supported when we empirically test it with data from the international market. We then classified the international markets into developed and developing countries and tested Hypothesis 1 in these two markets separately. As shown in Models 2

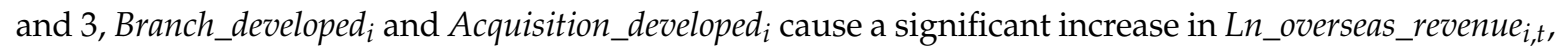
which suggests that establishing a branch or executing an M\&A in developed countries would increase the firm's revenue from that market. However, this effect is not significant in developing countries, where the parameter estimates of Branch_developed ${ }_{i}$ and Acquisition_developing $i$ are not significant. The political connection strength compensates for this insignificant impact by exhibiting a positive moderating effect on the relationship between Branch_developing ${ }_{i}$, (Acquisition_developing ${ }_{i}$ ), and Ln_overseas_revenue $e_{i, t}$ in Models 2 and 3. However, this moderating effect is not significant in developed countries. Therefore, Hypothesis 1 is confirmed when Chinese firms attempt to explore the international market positioned in developing countries, while it does not hold in the case of developed countries.

Models 4-7 test Hypothesis 2 by taking Ln_patent $i, t$ as the dependent variable. As shown in Model 4, the parameter estimate of $R D_{-}$center\&collaboration ${ }_{i}$ is significantly positive at a $10 \%$ level, suggesting that establishing international R\&D centers or collaborating with international firms on R\&D would improve a firm's innovation capability. Furthermore, this impact is positively moderated by political connection strength (i.e., the parameter estimate of Ln_Polit_connect_stren ${ }_{i} \times R D_{-}$center\&collaboration ${ }_{i}$ is significantly positive at a $10 \%$ level). However, these impacts are not significant when we take Ln_overseas_assets $i, t$ as the determinant of Ln_patent $t_{i, t}$ (See Model 5). Therefore, Model 4 provides evidence for Hypothesis 2, based on the whole international market. Next, we tested Hypothesis 2 with the data from developed and developing countries separately. Model 6 shows an insignificant regression result; that is, the parameter estimates of both Branch_developed ${ }_{i}$ and Branch_developing ${ }_{i}$ are not significant, and these effects are not significantly moderated by Ln_Polit_connect_stren $i$. However, the parameter estimates of $M \& A \_$developed ${ }_{i}$ are significantly positive, which suggests that executing an M\&A in developed countries would significantly increase the firm's innovation capability. Furthermore, it is evident that the government plays an important role in the process of the firm improving its innovation capability through M\&As in developed countries, which is demonstrated by the significantly positive parameter estimate of $L n_{-}$Polit_connect_stren ${ }_{i} \times M \& A_{-}$developed $_{i}$ in Model 6 . These effects are not significant in developing countries. Therefore, although our study provides evidence supporting Hypothesis 2, we believe that it is more likely to hold when a Chinese firm attempts to explore the international market in developed countries, but less likely to when considering developing countries.

We then drafted a moderating effect graph based on the regression results of Models 2, 3, 4 , and 7, where the moderating role of Ln_Polit_connect_stren $i_{i}$ was significantly positive. We also standardized the dependent variables when drafting the graph, with the intention of comparing the magnitude of the moderating effects between different dependent variables. As shown in Figure 2, political connection strength plays a positive moderating role by both increasing firms' international revenue in developing countries and by helping firms to acquire beneficial technology from developed countries. However, we further found that the magnitudes of the moderating effect were different in these two internationalization activities. This is illustrated by comparing the gradients of the red and blue lines, which exhibit greater differences in panels (c) and (d) than in panels (a) and (b) of Figure 2. This suggests that $L n_{-} P o l i t \_c o n n e c t \_s t r e n_{i}$ augments the positive effect of $M \& A \_$developed $i$ 
and $R D_{-}$center\&collaboration ${ }_{i}$ on $L n_{-}$patent ${ }_{i, t}$ to a greater extent, compared with its augmentation of

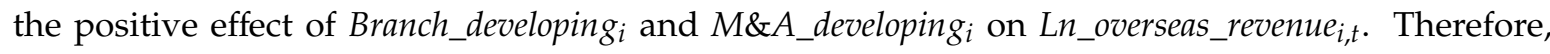
the political connection appears more effective for firms to acquire beneficial technology from other countries than to explore the international market.

Table 3. Regression results.

\begin{tabular}{|c|c|c|c|c|c|c|c|}
\hline \multirow[t]{2}{*}{ Dependent Variable } & \multicolumn{3}{|c|}{ Ln_overseas_revenue $e_{i, t}$} & \multicolumn{4}{|c|}{ Ln_patent $_{i, t}$} \\
\hline & $\begin{array}{c}\text { Model } 1 \\
\text { RE }^{a}\end{array}$ & $\begin{array}{c}\text { Model } 2 \\
\text { RE }\end{array}$ & $\begin{array}{c}\text { Model } 3 \\
\text { RE }\end{array}$ & $\begin{array}{c}\text { Model } 4 \\
\text { RE }\end{array}$ & $\begin{array}{c}\text { Model } 5 \\
\text { RE }\end{array}$ & $\begin{array}{c}\text { Model } 6 \\
\text { RE }\end{array}$ & $\begin{array}{c}\text { Model } 7 \\
\text { RE }\end{array}$ \\
\hline Constant & $\begin{array}{l}40.14^{* * *} \\
(13.32)\end{array}$ & $\begin{array}{c}39.13^{* * *} \\
(13.16)\end{array}$ & $\begin{array}{l}35.64^{* * *} \\
(13.30)\end{array}$ & $\begin{array}{c}-66.20 * * * \\
(10.02)\end{array}$ & $\begin{array}{c}-66.54 * * * \\
(10.03)\end{array}$ & $\begin{array}{c}-66.60 * * * \\
(10.06)\end{array}$ & $\begin{array}{c}-66.67^{* * *} \\
(10.03)\end{array}$ \\
\hline Listing_year $_{i}$ & $\begin{array}{l}-0.02 * * * \\
(0.01)\end{array}$ & $\begin{array}{c}-0.02 * * * \\
(0.01)\end{array}$ & $\begin{array}{c}-0.01 * * \\
(0.01)\end{array}$ & $\begin{array}{l}0.04^{* * *} \\
(0.005)\end{array}$ & $\begin{array}{l}0.04^{* * *} \\
(0.005)\end{array}$ & $\begin{array}{l}0.04^{* * *} \\
(0.005)\end{array}$ & $\begin{array}{l}0.04^{* * *} \\
(0.005)\end{array}$ \\
\hline \multicolumn{8}{|l|}{ Reference : West $t_{i}$} \\
\hline East $_{i}$ & $\begin{array}{l}0.87^{* * *} \\
(0.16)\end{array}$ & $\begin{array}{l}0.81^{* * *} \\
(0.15)\end{array}$ & $\begin{array}{l}0.86^{* * *} \\
(0.16)\end{array}$ & $\begin{array}{c}0.01 \\
(0.12)\end{array}$ & $\begin{array}{l}-0.01 \\
(0.12)\end{array}$ & $\begin{array}{c}-0.004 \\
(0.12)\end{array}$ & $\begin{array}{l}0.001 \\
(0.12)\end{array}$ \\
\hline Middle $_{i}$ & $\begin{array}{l}0.41^{* *} \\
(0.18)\end{array}$ & $\begin{array}{l}0.40^{* *} \\
(0.18)\end{array}$ & $\begin{array}{l}0.40^{* *} \\
(0.18)\end{array}$ & $\begin{array}{c}0.12 \\
(0.13)\end{array}$ & $\begin{array}{c}0.12 \\
(0.14)\end{array}$ & $\begin{array}{c}0.12 \\
(0.14)\end{array}$ & $\begin{array}{c}0.11 \\
(0.14)\end{array}$ \\
\hline Ln_staff $f_{i, t}$ & $\begin{array}{l}0.66^{* * *} \\
(0.04)\end{array}$ & $\begin{array}{l}0.64^{* * *} \\
(0.04)\end{array}$ & $\begin{array}{c}0.65^{* * *} \\
(0.04)\end{array}$ & & & & \\
\hline Ln_total_assets $s_{i, t}$ & $\begin{array}{l}0.32 * * * \\
(0.03)\end{array}$ & $\begin{array}{l}0.33^{* * *} \\
(0.03)\end{array}$ & $\begin{array}{c}0.33^{* * *} \\
(0.03)\end{array}$ & & & & \\
\hline$L n \_R D \_s t a f f_{i, t}$ & & & & $\begin{array}{l}0.24^{* * *} \\
(0.03)\end{array}$ & $\begin{array}{l}0.25^{* * *} \\
(0.03)\end{array}$ & $\begin{array}{l}0.24^{* * *} \\
(0.03)\end{array}$ & $\begin{array}{c}0.25^{* * *} \\
(0.03)\end{array}$ \\
\hline$L n \_R D \_i n v e s t m e n t t_{i, t}$ & & & & $\begin{array}{c}0.36^{* * *} \\
(0.02)\end{array}$ & $\begin{array}{c}0.36^{* * *} \\
(0.02)\end{array}$ & $\begin{array}{c}0.36^{* * *} \\
(0.02)\end{array}$ & $\begin{array}{l}0.36^{* * *} \\
(0.02)\end{array}$ \\
\hline Ln_overseas_assets $s_{i, t}$ & $\begin{array}{l}-0.003 \\
(0.01)\end{array}$ & & & & $\begin{array}{c}0.01 \\
(0.01)\end{array}$ & & \\
\hline$R D_{-}$center\&collaboration $i$ & & & & $\begin{array}{l}0.76^{*} \\
(0.47)\end{array}$ & & & \\
\hline \multicolumn{8}{|l|}{$\begin{array}{l}\text { Reference: No international } \\
\text { branch during 2013-2016 }\end{array}$} \\
\hline Branch_developed $_{i}$ & & $\begin{array}{l}1.10^{* *} \\
(0.51)\end{array}$ & & & & $\begin{array}{l}-0.07 \\
(0.39)\end{array}$ & \\
\hline Branch_developing ${ }_{i}$ & & $\begin{array}{c}1.16 \\
(0.77)\end{array}$ & & & & $\begin{array}{l}-0.32 \\
(0.60)\end{array}$ & \\
\hline \multicolumn{8}{|l|}{$\begin{array}{l}\text { Reference: No international } \\
\text { M\&A during 2013-2016 }\end{array}$} \\
\hline$M \& A \_$developed $_{i}$ & & & $\begin{array}{l}1.22 * \\
(0.73)\end{array}$ & & & & $\begin{array}{l}0.94^{*} \\
(0.57)\end{array}$ \\
\hline$M \& A \_$developing $i$ & & & $\begin{array}{c}0.51 \\
(1.78)\end{array}$ & & & & $\begin{array}{l}-1.80 \\
(1.35)\end{array}$ \\
\hline $\begin{array}{l}\text { Ln_Polit_connect_stren }_{i} \times \\
\text { Ln_overseas_assets } \\
\text { L }_{i, t}\end{array}$ & $\begin{array}{c}0.01 \\
(0.01)\end{array}$ & & & & $\begin{array}{l}-0.01 \\
(0.01)\end{array}$ & & \\
\hline $\begin{array}{l}\text { Ln_Polit_connect_stren } \\
R D \text { _center\&collaboration } \\
\text { R }\end{array}$ & & & & $\begin{array}{l}0.52 * \\
(0.30)\end{array}$ & & & \\
\hline $\begin{array}{c}\text { Ln_Polit_connect_stren }_{i} \times \\
\text { Branch_developed }_{i}\end{array}$ & & $\begin{array}{l}-0.22 \\
(0.28)\end{array}$ & & & & $\begin{array}{c}0.03 \\
(0.22)\end{array}$ & \\
\hline Ln_Polit_connect_stren ${ }_{i} \times$ & & $0.41^{* * *}$ & & & & 0.21 & \\
\hline Branch_developing ${ }_{i}$ & & $(0.11)$ & & & & $(0.32)$ & \\
\hline $\begin{array}{c}\text { Ln_Polit_connect_stren }_{i} \times \\
\text { M\&A developed }\end{array}$ & & & $\begin{array}{l}-0.34 \\
(0.41)\end{array}$ & & & & $\begin{array}{l}0.44^{* *} \\
(0.21)\end{array}$ \\
\hline $\begin{array}{l}\text { Ln_Polit_connect_stren } \\
\quad M \& A \_d e v e l o p i n g \\
\end{array}$ & & & $\begin{array}{l}0.33^{* *} \\
(0.15)\end{array}$ & & & & $\begin{array}{c}0.95 \\
(0.74)\end{array}$ \\
\hline Number of observations & 6092 & 6092 & 6092 & 6030 & 6030 & 6030 & 6030 \\
\hline Number of groups & 1996 & 1996 & 1996 & 1969 & 1969 & 1969 & 1969 \\
\hline Wald chi-squared & 1587.05 & 1692.93 & 1610.43 & 626.93 & 618.55 & 617.23 & 624.71 \\
\hline Prob $>$ chi-squared & 0.00 & 0.00 & 0.00 & 0.00 & 0.00 & 0.00 & 0.00 \\
\hline $\mathrm{R}^{2}$ & 0.35 & 0.37 & 0.36 & 0.21 & 0.20 & 0.20 & 0.21 \\
\hline
\end{tabular}

Note: ${ }^{a} \mathrm{RE}$ is the acronym of Radom Effect. ${ }^{* * *}, * *$, and $*$ denotes that the parameter estimates are significant at $1 \%$, $5 \%$, and $10 \%$, respectively. 


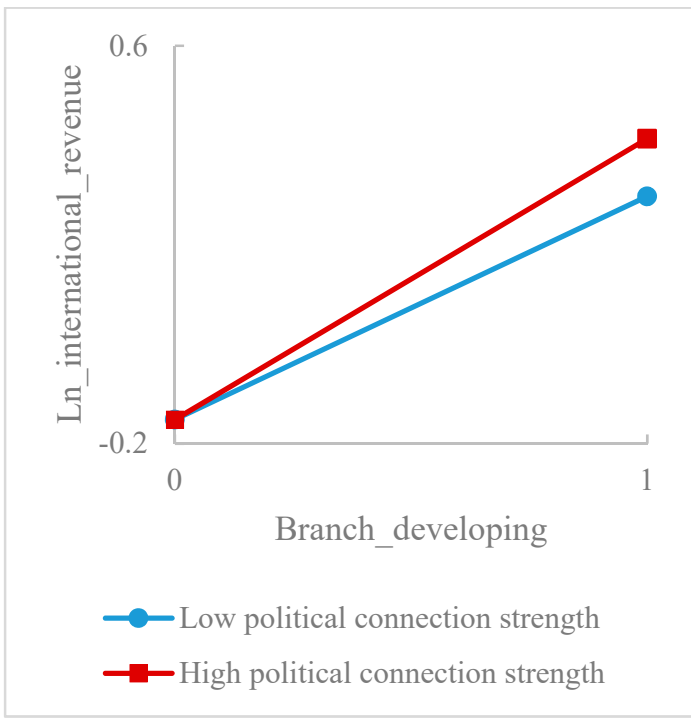

(a)

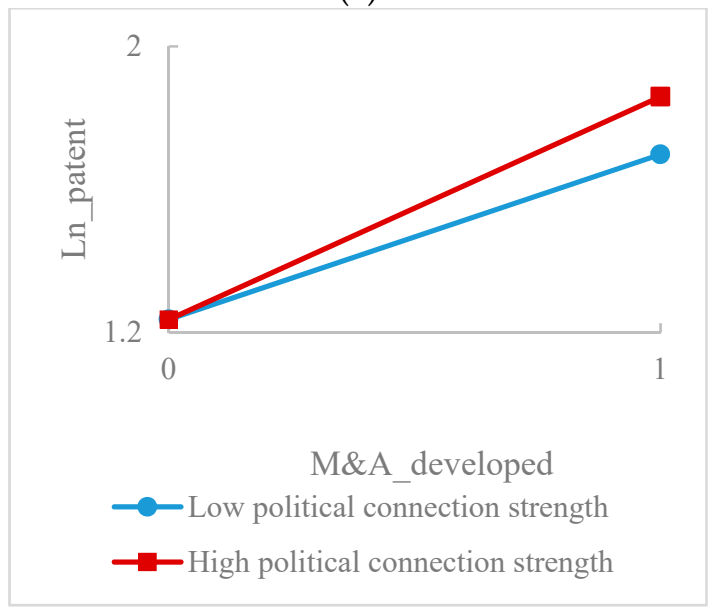

(c)

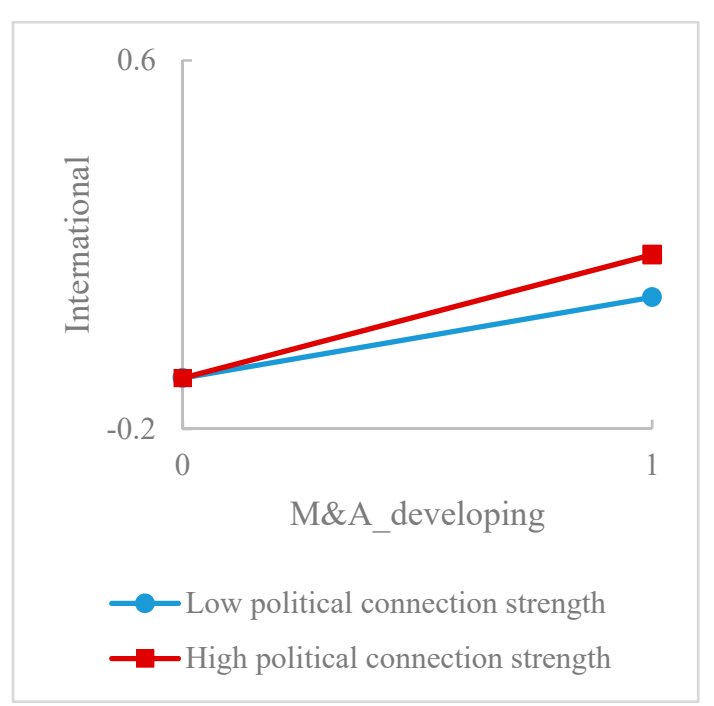

(b)

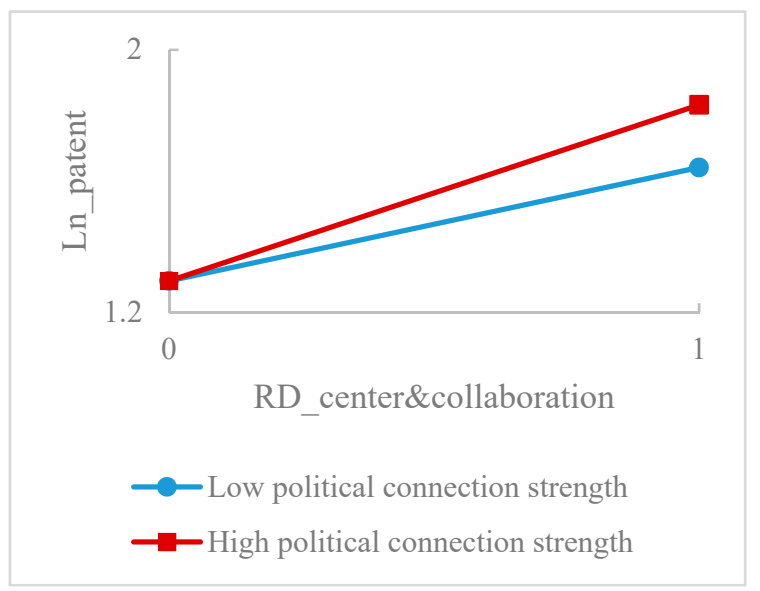

(d)

Figure 2. Moderating effect of political connection strength. Note: $L n \_$overseas_revenue $i, t$ and $L n \_p a t e n t_{i, t}$ in Figure 2 have been standardized by first subtracting their average value and then dividing it by their standard deviation, so that a comparison of the variations between Ln_overseas_revenue $i, t$ and $L_{n} \_$patent $_{i, t}$ can be made.

\section{Discussion}

Firms from emerging economies face the challenge of internationalization in the absence of significantly superior technological and managerial resources [68]. However, the rapid expansion of Chinese firms in the international market suggests that they may have overcome these disadvantages. To a great extent, this can be attributed to the Chinese government, which acts as an important institutional force, an influence that has been underappreciated for a long time [68]. However, there is a gap in empirical literature concerning the effectiveness of the Chinese government's role in Chinese firms' internationalization. This study complements existing literature by empirically investigating how Chinese firms' political connection with their home country government impacts the outcomes of their internationalization activities.

Our results show that a strong political connection with the Chinese government would assist in realizing two main internationalization motives: market exploration from developing countries and technology acquisition from developed countries. The determinant of these specific government roles in different market contexts and internationalization motives may be that the government 
intentionally compensates for firms' disadvantages in their internationalization processes. For example, for technology acquisition, extremely high expenses may impede Chinese firms in acquiring a high-tech firm in a developed country. Instead, the Chinese government could assist domestic firms in acquiring technologies from developed countries by providing financial assistance, such as establishing investment funds to finance domestic firms' acquisition abroad or by directing domestic firms to make a venture capital investment in the high-tech industries of developed countries [45]. Considering international market exploration, as the market freedom in developed countries is relatively high, the competition among firms determines the outcome of internationalization to a great extent, while the home country government can play almost no role in domestic firms' business operation in developed countries. In comparison, due to widespread political instability and economic and policy risks in the markets of developing countries [49,69], a bilateral treaty between the governments of home and host countries could be a useful tool for firms targeting the markets of developing countries to avoid these risks [70]. Therefore, it appears that the Chinese government functions well in the area where domestic firms need outside assistance, thereby compensating for the disadvantages of the firms in the internationalization process. By discovering the positive moderating role of the Chinese government in increasing domestic firms' international revenue through OFDI, our study goes one step further by confirming political connections' effect on the outcome of domestic firms' internationalization, thereby extending knowledge offered by existing studies such as that of [71] that focused on the relationship between Chinese government and the OFDI of domestic firms.

Political connection strength has a more significant moderating effect on international technology acquisition than on international market exploration, which may be because the Chinese government appears to be more successful in assisting domestic firms to acquire international technology. Chinese firms are mostly uncompetitive in innovation capability [44]. To compensate for this disadvantage, the Chinese government enacted many policies and support strategies to facilitate domestic firms' acquisition of technology from developed countries to ensure the sustainability of firms' internationalization and performance. It also appears that with the assistance of the Chinese government, Chinese firms perform well in enhancing the innovation capability by acquiring and improving international technologies, such as the high-speed railway, 4G, quantum communication, and aerospace technology. The success in technology acquisition intangibly pushed by the Chinese government has attracted much attention from many countries' governments, such as the United States, who claimed an intellectual property loss of billions of dollars [45]. In comparison, the Chinese government pushed international market exploration, which is currently facing difficulties. For example, China's "Belt and Road" initiative has recently been experiencing pushback from various countries, such as Malaysia, Sri Lanka, Zambia, and even Pakistan (China's belt and road initiative: Why the price is too high. https://knowledge.wharton.upenn.edu/article/chinas-belt-and-road-initiative-why-theprice-is-too-high.), where the gains appear non-commensurate with the projected investments in the "Belt and Road" initiative. These may be some of the main causes of the Chinese government playing a more significant role in Chinese firms' international technology acquisition than in international market exploration.

\section{Conclusions}

This study analyzes the relationship between firms' political connection with their home country government and their internationalization processes by examining the role of political connection in moderating the impact of internationalization activity on its outcomes. We focused on two internationalization motives: international market exploration and technology acquisition and classified the international market into developed and developing countries. Our empirical analysis of 1996 Chinese listed firms shows that the political connection strength exhibits a bimodal distribution, which suggests that some firms maintain a close relationship with the Chinese government, while most other firms are relatively distant from the Chinese government. Considering firms with a strong political connection with the Chinese government, these firms perform better in exploring the market 
in developing countries and acquiring beneficial technology from developed countries. It is therefore evident that the Chinese government is an important driving force that urges domestic firms to implement the "going out strategy," as well as a key factor that ensures the effectiveness of the firms' internationalization activity.

Our study has important policy implications. The government may need to reduce its intervention in business, while the trend of government intervention has been increasing since late 2008 [72], particularly those governments in emerging countries. Although government-backed internationalization has proved to be successful, it has led to a market distortion and has changed the behavior of domestic firms, which may be harmful to firms' competitiveness in the context of the market economy. Due to the influence of government policies, firms often need to consider the pressure of multiple political, economic, and social goals, which could lead to a loss of firms' decision-making power. The influence of political intervention often leads to the reduction of resource utilization efficiency and weakened management motivation [73]. Additionally, government-backed internationalization has recently been highly concerning to developed markets, who tend to view this internationalization activity as inappropriate and have taken measures to scrutinize international firms' political background. For example, Huawei, Haihang, and other Chinese firms have been blocked by the governments of some other countries when they attempted to acquire international firms located in Europe and the United States.

This study also has certain limitations that future research should address. First, as Chinese governments usually impact firms' internationalization through policies, it is necessary to empirically quantify the government's policies and investigate their impacts. In this study, quantifying the political connection strength could only reflect the closeness of the relationship between the firm and the government, who may issue an array of different policies and supports, each of which may impact only a group of firms under certain contexts. Our study could not clearly differentiate these effects. Future studies should investigate the policy dimension more deeply-particularly major policies like the Chinese government's "Belt and Road" initiative that may generate significant effects-and examine the internationalization outcomes of firms who actively participate in this initiative.

Second, our measurement of the political connection strength needs to be further improved. Similar to most existing studies, our questionnaire accounted for only the political connection of the listed firm's board chairperson and general manager. It may be necessary to explore the political connections of other firm members or senior personnel, because the key political connection is usually held by other board members like the vice chairperson or vice general manager. Additionally, we may need to enlarge the coverage of our survey, as this study only surveyed 104 experts.

Author Contributions: D.H. wrote the paper. Q.Z. proposed the research topic, carried out the survey and collected the data. G.Z. made the empirical analysis and proofread the paper. All authors have read and agreed to the published version of the manuscript.

Funding: This research was funded by [National Natural Science Foundation of China] grant number [71872169, 71874177, 71810107004, 71772014], [Beijing Natural Science Foundation] grant number [9202019], [University of Chinese Academy of Sciences] grant number [Y8540XX1P2] And [Bureau of Planning and Strategy, Chinese Academy of Sciences] grant number [GHJZLZX-2019-33-2].

Acknowledgments: The authors highly appreciate the precious comments from 3 anonymous reviewers.

Conflicts of Interest: The authors declare no conflict of interest.

\section{References}

1. Luo, Y.D.; Tung, R.L. International expansion of emerging market enterprises: A springboard perspective. J. Int. Bus. Stud. 2007, 38, 481-498. [CrossRef]

2. Tan, H.; Mathews, J.A. Accelerated internationalization and resource leverage strategizing: The case of Chinese wind turbine manufacturers. J. World Bus. 2015, 50, 417-427. [CrossRef]

3. Zhang, J.; Tan, J.; Wong, P.K. When does investment in political ties improve firm performance? The contingent effect of innovation activities. Asia Pac. J. Manag. 2015, 32, 363-387. [CrossRef] 
4. Luo, Y.D.; Xue, Q.Z.; Han, B.J. How emerging market governments promote outward FDI: Experience from China. J. World Bus. 2010, 45, 68-79. [CrossRef]

5. Luo, Y.; Zhang, H. Emerging market MNEs: Qualitative review and theoretical directions. J. Int. Manag. 2016, 22, 333-350. [CrossRef]

6. Ramasamy, B.; Yeung, M.; Laforet, S. China's outward foreign direct investment: Location choice and firm ownership. J. World Bus. 2012, 47, 17-25. [CrossRef]

7. Alon, I.; Anderson, J.; Munim, Z.H.; Ho, A. A review of the internationalization of Chinese enterprises. Asia Pac. J. Manag. 2018, 35, 573-605. [CrossRef]

8. Guillén, M.F.; García-Canal, E. The American model of the multinational firm and the new multinationals from emerging economies. Acad. Manag. Perspect. 2009, 23, 23-35. [CrossRef]

9. Ramamurti, R. Competing with emerging market multinationals. Bus. Horiz. 2012, 55, 241-249. [CrossRef]

10. Buckley, P.J.; Clegg, L.J.; Cross, A.R.; Liu, X.; Voss, H.; Zheng, P. The determinants of Chinese outward foreign direct investment. J. Int. Bus. Stud. 2007, 38, 499-518. [CrossRef]

11. Deng, P. Why do Chinese firms tend to acquire strategic assets in international expansion? J. World Bus. 2009, 44, 74-84. [CrossRef]

12. Petricevic, O.; Teece, D.J. The structural reshaping of globalization: Implications for strategic sectors, profiting from innovation, and the multinational enterprise. J. Int. Bus. Stud. 2019, 50, 1487-1512. [CrossRef]

13. Deng, P. Outward investment by Chinese MNEs: Motivations and implications. Bus. Horiz. 2004, 47, 8-16. [CrossRef]

14. Li, F.R.; Ding, D.Z. The effect of institutional isomorphic pressure on the internationalization of firms in an emerging economy: Evidence from China. Asia Pac. Bus. Rev. 2013, 19, 506-525. [CrossRef]

15. Du, M.; Baoteng, A. State ownership, institutional effects and value creation in cross-border mergers \& acquisitions by Chinese firms. Int. Bus. Rev. 2015, 24, 430-442.

16. Angulo-Ruiz, F.; Pergelova, A.; Wei, W.X. How does home government influence the internationalization of emerging market firms? The mediating role of strategic intents to internationalize. Int. J. Emerg. Mark. 2018, 14, 187-206. [CrossRef]

17. Minin, A.D.; Zhang, J.Y.; Gammeltoft, P. Chinese foreign direct investment in R\&D in Europe: A new model of R\&D internationalization? Eur. Manag. J. 2012, 30, 189-203.

18. Hitt, M.A.; $\mathrm{Xu}, \mathrm{K}$. The Transformation of China: Effects of the institutional environment on business actions. Long Range Plan. 2016, 49, 589-593. [CrossRef]

19. Wu, W.F.; Wu, C.F.; Zhou, C.Y.; Wu, J. Political connections, tax benefits and firm performance: Evidence from China. J. Account. Public Policy 2012, 31, 277-300. [CrossRef]

20. Zhang, H.M.; Li, L.S.; Zhou, D.Q.; Zhou, P. Political connections, government subsidies and firm financial performance: Evidence from renewable energy manufacturing in China. Renew. Energy 2014, 63, 330-336. [CrossRef]

21. Mathews, J.A. Dragon Multinationals: A New Model of Global Growth; Oxford University Press: New York, NY, USA, 2002.

22. Mathews, J.A. Dragon multinationals powered by linkage, leverage and learning: A review and development. Asia Pac. J. Manag. 2017, 34, 769-775. [CrossRef]

23. Aulakh, P.S. Emerging multinationals from developing economies: Motivations, paths and performance. J. Int. Manag. 2007, 13, 235-240. [CrossRef]

24. Zeng, R.; Zeng, S.; Xie, X.; Tam, C.; Wan, T. What motivates firms from emerging economies to go internationalization? Technol. Econ. Dev. Econ. 2012, 18, 280-298. [CrossRef]

25. Ramamurti, R. Internationalization and innovation in emerging markets. Strateg. Manag. J. 2016, 37, E74-E83. [CrossRef]

26. Zhang, X.; Ma, X.; Wang, Y.; Li, X.; Huo, D. What drives the internationalization of Chinese SMEs? The joint effects of international entrepreneurship characteristics, network ties, and firm ownership. Int. Bus. Rev. 2016, 25, 522-534. [CrossRef]

27. Wu, B.Z. Political connections and entrepreneurial investment: Evidence from China's transition economy. J. Bus. Ventur. 2013, 28, 299-315.

28. Lu, J.; Liu, X.; Filatotchev, I.; Wright, M. The impact of domestic diversification and top management teams on the international diversification of Chinese firms. Int. Bus. Rev. 2014, 23, 455-467. [CrossRef] 
29. Ma, X.F.; Ding, Z.J.; Lin, Y. Subnational institutions, political capital, and the internationalization of entrepreneurial firms in emerging economies. J. World Bus. 2016, 51, 843-854. [CrossRef]

30. Wu, J.; Wang, C.; Hong, J.; Piperopoulos, P.; Zhuo, S. Internationalization and innovation performance of emerging market enterprises: The role of host-country institutional development. J. World Bus. 2016, 51, 251-263. [CrossRef]

31. Dunning, J. The eclectic paradigm of international production: A statement and some possible extensions. J. Int. Bus. Stud. 1988, 19, 1-31. [CrossRef]

32. Lin, C.; Klaus, E.M.; Helen, W.H. What drives firms' intent to seek strategic assets by foreign direct investment? A study of emerging economy firms. J. World Bus. 2014, 49, 488-501.

33. Faccio, M. Politically connected firms. Am. Econ. Rev. 2006, 96, 369-386. [CrossRef]

34. Wu, J. Asymmetric roles of business ties and political ties in product innovation. J. Bus. Res. 2011, 64, 1151-1156. [CrossRef]

35. Hou, Q.; Hu, M.; Yuan, Y. Corporate innovation and political connections in Chinese listed firms. Pac. Basin Financ. J. 2017, 46, 158-176. [CrossRef]

36. Guo, D.; Guo, Y.; Jiang, K. Government-subsidized R\&D and firm innovation: Evidence from China. Res. Policy 2016, 45, 1129-1144.

37. Song, M.; Ai, H.; Li, X. Political connections, financing constraints, and the optimization of innovation efficiency among China's private enterprises. Technol. Forecast. Soc. Chang. 2015, 92, 290-299. [CrossRef]

38. Hong, J.; Wang, C.; Kafouros, M. The role of the state in explaining the internationalization of emerging market enterprises. Br. J. Manag. 2015, 26, 45-62. [CrossRef]

39. Peng, M.W.; Wang, D.Y.L.; Jiang, Y. An institution-based view of international business strategy: A focus on emerging economies. J. Int. Bus. Stud. 2008, 39, 920-936. [CrossRef]

40. Lu, J.; Liu, X.; Wang, H. Motives for outward FDI of Chinese private firms: Firm resources, industry dynamics, and government policies. Manag. Organ. Rev. 2011, 7, 223-248. [CrossRef]

41. Child, J.; Rodrigues, S.B. The internationalization of Chinese firms: A case for theoretical extension? Manag. Organ. Rev. 2005, 1, 381-410. [CrossRef]

42. Tung, R.L. Opportunities and challenges ahead of China's new normal. Long Range Plan. 2016, 49, 632-640. [CrossRef]

43. Cheng, J.L.C.; Yiu, D. China Business at a Crossroads: Institutions, Innovation, and International Competitiveness. Long Range Plan. 2016, 49, 584-588. [CrossRef]

44. Rugman, A.M.; Nguyen, Q.T.K.; Wei, Z. Rethinking the literature on the performance of Chinese multinational enterprises. Manag. Organ. Rev. 2016, 12, 269-302. [CrossRef]

45. O'Connor, S. How Chinese Companies Facilitate Technology Transfer from the United States. Available online: http:/www.defense-aerospace.com/articles-view/release/3/202365/report-details-howchinese-companies-steal-us-technology.html (accessed on 12 October 2019).

46. Yu, F.F.; Guo, Y.; Le-Nguyen, K.; Barnes, S.J.; Zhang, W.T. The impact of government subsidies and enterprises' R\&D investment: A panel data study from renewable energy in China. Energy Policy 2016, 89, 106-113.

47. Li, F.R.; Ding, D.Z.; Oh, C.H. The dual effects of home country institutions on the internationalization of private firms in emerging markets: Evidence from China. Multinatl. Bus. Rev. 2017, 25, 128-149. [CrossRef]

48. Wang, C.; Hong, J.; Kafouros, M.; Boateng, A. What drives outward FDI of Chinese firms? Testing the explanatory power of three theoretical frameworks. Int. Bus. Rev. 2012, 21, 425-438. [CrossRef]

49. Wang, Y.B.; Li, J.Z.; Furman, J.L. Firm performance and state innovation funding: Evidence from China's Innofund program. Res. Policy 2017, 46, 1142-1161. [CrossRef]

50. Buckley, P.; Cross, A.R.; Tan, H.; Voss, H.; Liu, X. Historic and emergent trends in Chinese outward direct investment. Manag. Int. Rev. 2008, 48, 715-748. [CrossRef]

51. Errunza, V.R.; Senbet, L.W. The Effects of international operations on the market value of the firm: Theory and evidence. J. Financ. 1984, 36, 401-417. [CrossRef]

52. Capar, N.; Kotabe, M. The relationship between international diversification and performance in service firms. J. Int. Bus. Stud. 2003, 34, 345-355. [CrossRef]

53. Jeong, I. A cross-national study of the relationship between international diversification and new product performance. Int. Mark. Rev. 2003, 20, 353-376. [CrossRef]

54. Griliches, Z. Patent statistics as economic indicators: A survey. J. Econ. Lit. 1990, 28, 1661-1707. 
55. Arnoldi, J.; Villadsen, A.R. Political ties of listed Chinese companies, performance effects, and moderating institutional factors. Manag. Organ. Rev. 2015, 11, 217-236. [CrossRef]

56. Fisman, R.; Wang, Y. The mortality cost of political connections. Rev. Econ. Stud. 2015, 82, 1346-1382. [CrossRef]

57. Huang, P. The verticality of policy mixes for sustainability transitions: A case study of solar water heating in China. Res. Policy 2019, 48, 103-758. [CrossRef]

58. Armstrong, S.J.; Overton, T. Estimating non-response bias in mail surveys. J. Mark. Res. 1977, 14, $396-402$. [CrossRef]

59. Sambharya, R.B. The combined effect of international diversification and product diversification strategies on the performance of U.S.-based multinational corporations. Manag. Int. Rev..

60. Gomes, L.; Ramaswamy, K. An empirical examination of the form of the relationship between multinationality and performance. J. Int. Bus. Stud. 1999, 30, 173-188. [CrossRef]

61. El ghoul, S.; Guedhami, O.; Kim, Y. Country level institutions, firm value, and the role of corporate social responsibility initiatives. J. Int. Bus. Stud. 2017, 48, 360-385. [CrossRef]

62. Li, J.; Zhang, Y.; Hu, Y.H.; Tao, X.L. Developed market or developing market? A perspective of institutional theory on multinational enterprises' diversification and sustainable development with environmental protection. Bus. Strategy Environ. 2018, 27, 858-871. [CrossRef]

63. Beule, F.D.; Elia, S.; Piscitello, L. Entry and access to competencies abroad: Emerging market firms versus advanced market firms. J. Int. Manag. 2014, 20, 137-152. [CrossRef]

64. Bhanji, Z.; Oxley, J.E. Overcoming the dual liability of foreignness and privateness in international corporate citizenship partnerships. J. Int. Bus. Stud. 2013, 44, 290-311. [CrossRef]

65. Gruca, T.S.; Rego, L.L. Customer satisfaction, cash flow, and shareholder value. J. Mark. 2005, 69, 115-130. [CrossRef]

66. Luo, X.; Bhattacharya, C.B. Corporate social responsibility, customer satisfaction, and market value. J. Mark. 2006, 70, 1-18. [CrossRef]

67. Gaur, A.S.; Kumar, V.; Singh, D. Institutions, resources, and internationalization of emerging economy firms Website address. J. World Bus. 2014, 49, 12-20. [CrossRef]

68. Peng, M.W. The global strategy of emerging multinationals from China. Glob. Strategy J. 2012, 2, 97-107. [CrossRef]

69. Li, J.; Oh, C.H. Research on emerging-market multinational enterprises: Extending Alan Rugman's critical contributions. Int. Bus. Rev. 2016, 25, 776-784. [CrossRef]

70. Gammeltoft, P.; Filatotchev, I.; Hobdari, B. Emerging multinational companies and strategic fit: A contingency framework and future research agenda. Eur. Manag. J. 2012, 30, 175-188. [CrossRef]

71. Yu, S.; Qian, X.W.; Liu, T.X. Belt and road initiative and Chinese firms' outward foreign direct investment. Emerg. Mark. Rev. 2019, 41, 100629. [CrossRef]

72. Windsor, D. Tightening corporate governance. J. Int. Manag. 2009, 15, 306-316. [CrossRef]

73. Wu, J.; Chen, X. Home country institutional environments and foreign expansion of emerging market firms. Int. Bus. Rev. 2014, 23, 862-872. [CrossRef]

(C) 2020 by the authors. Licensee MDPI, Basel, Switzerland. This article is an open access article distributed under the terms and conditions of the Creative Commons Attribution (CC BY) license (http://creativecommons.org/licenses/by/4.0/). 